\title{
Inflating the Prestige of Demons
}

\author{
Johan Wier's Role-Playing
}

\author{
Hans de Waardt \\ Vrije Universiteit Amsterdam, Amsterdam, The Netherlands \\ johannesdewaardt@gmail.com
}

\begin{abstract}
In the sixteenth century, witchcraft was generally thought to be a grave danger. Specific people, a majority of them women, were believed to threaten the world as servants of the Devil. In his De praestigiis daemonum, published in 1563, the Dutch / German physician Johan Wier argued that human beings were unable to perform witchcraft and that the women who were accused were innocent but often deluded by demons into believing that they were guilty. In his plea for tolerance Wier was inspired by his brother Matthias and the spiritualist prophet David Joris. In order to convince his readers he used their prejudices, that he himself rejected, about the power of demons and the intellectual capacities of women.
\end{abstract}

\section{Keywords}

Johan Wier - De praestigiis daemonum - Matthias Wier - witchcraft - demonic power tolerance

In sixteenth-century Europe witchcraft was considered a major problem. Many learned theologians and magistrates believed that witches had concluded a pact with the devil to wreak havoc with his assistance. ${ }^{1}$ It should, however, be emphasised that this view was not adopted unimpaired. ${ }^{2}$ The spiritualist

1 The major analysis of this subject is without doubt the magisterial study of Stuart Clark, Thinking with Demons: The Idea of Witchcraft in Early Modern Europe (Oxford, 1997).

2 On this see Walter Stephens, Demon Lovers: Witchcraft, Sex, and the Crisis of Belief (Chicago, 2003). 
conception of the universe for one thing fundamentally undermined the basis for this view by postulating that the devil was not an anthropomorphic entity but the principle of evil that is present in every person. A demonic pact with such an abstract principle was impossible. It is argued here that the physician Johan Wier (1515-1588) was inspired by the teachings of his brother Matthias Wier and the spiritualist David Joris in his opposition to the prosecution of supposed witches. In order for this stance to be effective, he seemingly embraced dominant demonological conceptions, but only to carry these to their ultimate consequences. By stating it was the devil and his demons who did evil in the world, but then deluded humans to believe that specific women were the guilty ones, he tried to exonerate these usual suspects. In none of the biographies of Wier that have appeared thus far is this aspect discussed thoroughly. ${ }^{3}$ This is mainly due to the fact that relevant sources have been overlooked or not analysed enough to spot this important element.

Johan Wier's fame mainly rests on his De praestigiis daemonum (On the Illusions of Demons), the first edition of which appeared in 1563 in Basel with Johannes Oporinus (1507-1568). ${ }^{4}$ New issues followed in $1564,1566,1568,1577$, and 1583 , each time with Oporinus or his heirs. In general, Wier's biographers base their analysis of his line of arguing and thinking on the sixth and last edition of 1583 . It is part of the Opera Omnia that appeared in Amsterdam in 166o, and was also the basis of the English translation of 1991. ${ }^{5}$ This suggests that the 1583 edition was not only the last, but also the final version. It needs, however, to be emphasized that, had he lived longer, Wier would have altered its contents

3 Some of the more noteworthy studies are: Carl Binz, Doctor Johann Weyer, ein rheinischer Arzt, der erste Bekämpfer des Hexenwahns: Ein Beitrag zur Geschichte der Aufklärung und der Heilkunde (Berlin, 1896). For its time this was a ground-breaking study. The biography by the Dutch physician J.J. Cobben, Jan Wier, Devils, Witches and Magic (Philadelphia, 1976), added many details drawn from archival sources. The best biography is at present the study by the Italian scholar Michaela Valente, Johann Wier: agli albori della critica razionale dell'occulto e del demoniaco nell'Europa del Cinquecento (Firenze, 2003). A number of often highly relevant sources were, however, not used by her, perhaps because many of them are in Dutch. The present article is an addition to my "Witchcraft, Spiritualism and Medicine: The Religious Convictions of Johan Wier," Sixteenth Century Journal 42 (2011), 369-391. I am preparing a monograph in which this matter and many until-now undetected aspects of Wier's life will be discussed.

4 Johan Wier, De praestigiis daemonum, et incantationibus ac veneficijs, libri v (Basel: Oporinus, 1563). Johan Wier, Witches, Devils, and Doctors in the Renaissance:Johann Weyer, De praestigiis daemonum, ed. George Mora, Benjamin Kohl, John Shea, and Erik Midelfort (Binghamton, 1991).

5 Johan Wier, Opera omnia (Amsterdam: Pieter van den Berghe, 166o); Wier, Witches, Devils, and Doctors (see above, n. 4). 
yet again. Each time, as will be seen, Wier added, removed, or altered words or sentences, and added or re-phrased paragraphs or indeed whole chapters. In 1564 he re-arranged the structure of his book by introducing a breakdown in chapters. The first three editions of De praestigiis contain five books, but the fourth one of 1568 has six. De praestigiis daemonum was and remained a work in progress. Another aspect, one that is of particular interest here, is that Wier used new editions, particularly that of 1577 , to disclose feelings and beliefs that inspired or even guided him. Perhaps "disclose" is not the right term, because he habitually used a sort of coded phrasing. ${ }^{6}$ Another major deficit of most studies of his life and work is their relative neglect of his many other publications. And finally, the translations of his works that he himself produced and especially their forewords are barely touched upon in most studies. This contribution will show, in fact, that these introductory notes shed considerable light on Wier and his personal convictions.

The central element of all of the De praestigiis editions is Wier's argument that human beings, in his case always women, should not be prosecuted for witchcraft. Even suspects who are convinced that they caused setbacks and disasters are in truth misled by demons who in reality do all the evil. The reason why these women are open to this fraud is, apart from the general weakmindedness of the female gender, the fact that many of them are suffering from melancholy. This enables the demons to take possession of their brains and minds after which they can delude their victims with all sorts of illusions. Wier showed himself to be a faithful follower of Galen, the classical authority of medicine whose works were printed extensively in the sixteenth century and for a prolonged period dominated the field. ${ }^{7}$ Galen taught that a person is healthy if the four humours (blood, yellow bile, black bile, and phlegm) are in balance. If there is an excess of one of them, in this case black bile, the patient will fall ill and become melancholic. So, Wier argued, these women are innocent and should not be tried, tortured and executed, but referred to physicians.

\section{$1 \quad$ Wier's Introduction to Natural Magic}

In January and March 1529 Heinrich Cornelius Agrippa ab Nettesheim (14861535), ${ }^{8}$ a famous humanist but also a notorious advocate of natural magic, cor-

6 A first survey of such encodings is De Waardt, "Witchcraft, Spiritualism and Medicine" (see above, n. 3).

7 Susan P. Mattern, Galen and the Rhetoric of Healing (Baltimore, 2008), 13.

8 The standard biographical study on Agrippa still is Charles G. Nauert, Agrippa and the Cri- 
responded with a studiosus called "Joannes" who was about to join his household. ${ }^{9}$ Johan stayed with Agrippa until 1533, during the years when his mentor was preparing his two main works for the printing press, which implies that Johan was fully familiar with Agrippa's magical thinking. ${ }^{10}$ Wier himself tells us that he found much in Agrippa's library about magic, for instance the Steganographia of the abbot Trithemius who had been instrumental in Agrippa's introduction to that field. ${ }^{11}$ Johan took great interest in these works; he not only read them, but also copied parts of them without his mentor noticing it. He also got actively involved in Agrippa's lab research. Shortly after Wier's arrival in Antwerp, his mentor, who was also a medical doctor, was called away to Mechelen to attend to a patient. From there he corresponded with an unnamed member of his household about amongst other things the progress of alchemical tests in his laboratory. The letters are in Latin and there was at that time only one person in his household who commanded this language: young Johan. ${ }^{12}$ In other words, Agrippa's pupil was closely involved in his mentor's alchemical experiments. We may therefore assume that during his years in Agrippa's household he received not only a scholarly training, but also an introduction to the art of careful alchemical observing, in other words to natural magic.

sis of Renaissance Thought (Urbana, 1965). But see also Marc van der Poel, Cornelius Agrippa: The Humanist Theologian and his Declamations (Leiden, 1997); Christopher I. Lehrich, The Language of Demons and Angels: Cornelius Agrippa's Occult Philosophy (Leiden, 2003).

9 Agrippa ab Nettesheim, Opera, Pars IV (Lyon [= Strasbourg]: Beringi [= Zetzner], 16oo), Epistolarum Liber IV, 262-264, 265-266, nrs. LXV and LXVII. As to the publisher, see Andrew Pettegree and Malcolm Walsby, French Books Published in France before 1601 in Latin and Languages other than French (Leiden, 2012), 12, nr. $5^{2034}$.

10 These are Henricus Cornelius ab Nettesheim, De incertitudine et vanitate scientiarum et artium, atque excellentia verbi Dei declamatio (Antwerp: Joannes Grapheus, 1530); and De occulta philosophia libri tres ([Antwerp]: Joannes Grapheus, 1531). On these two editions see Andrew Pettegree and Malcolm Walsby, Netherlandish Books: Books Published in the Low Countries and Dutch Books Printed abroad before 160o, 2 vols. (Leiden, 2011), 1: 11, nrs. 251 and 256. In his Occulta Philosophia, Agrippa discusses the sub-domains-of which there were many_ of natural magic. See Brian P. Copenhaver, Magic in Western Culture: From Antiquity to the Enlightenment (Cambridge, 2015), 40.

11 He added this information in De praestigiis (1564), 130. He must have read a manuscript of the Steganographia which only went to press for the first time almost eighty years later: Johannes Trithemius, Steganographia: Hoc est: Ars per occultam scripturam animi sui voluntatem absentibus aperiendi certa (Frankfurt: Berner, 16o6).

12 Werner Gelderblom, Marc van der Poel, and L. Scholten, "Twelve Letters on Alchemy from the Correspondence of Agrippa von Nettesheim (Epistolae II.51, 52, 56, IV.27, 56, 71, V.2, 7276)," Lias 34 (2007), 137-188. 
A further exploration of what was happening in that subject round 1500 seems therefore to be called for here. ${ }^{13}$ In the 146 os the Florentine humanist Marsilio Ficino (1433-1499) translated into Latin the dialogues of Plato and the Enneads of the third-century Platonist philosopher Plotinus (ca. 204/5270). ${ }^{14}$ Ficino's translations led to a revival of Platonism in humanist circles, which together with the texts ascribed to the wholly mythical know-it-all Hermes Trismegistus, generated a new understanding of the cosmos and the place of humanity in it: Natural Magic, the conviction that humans could manipulate nature by incantations and control over spirits.

To get as close to God as possible, or even better, to merge with him was the essential goal. Alchemy was one of the means to help bring this about. For natural magicians, alchemy was not so much a means to produce gold, but a tool to understand the intentions of God's creation by observing as closely as possible the process of transmutation of metals and other substances. This was believed to facilitate a deeper understanding of God himself.

As a true Platonist, Plotinus postulated a dualism between a supernatural and an inferior visible world. ${ }^{15}$ At the top of it all was the One, the principle that encompasses everything. From the One emanates what in Greek is called the Nous, and can at best be - somewhat insufficiently — translated as Intellect or Understanding. From the Nous emanates the world soul Psyche that actually consists of two elements: a higher one and a lower one, which is nature; from Psyche emanates Matter.

The One is not just an intellectual concept but also something that can be experienced. Humans who are a mix of soul and matter (psyche and soma) need, in order to gain true insight, to climb from Psyche to Nous and hence to the One. To that end they have to suppress in themselves the material aspects of their being. The final goal is enosis or symbiosis with the One, which, however, during life on earth is only possible occasionally and very briefly. The journey to the One is a complicated individual enterprise and nobody can decide whether another individual is doing it the right way. Tolerance then is a consequence.

Ficino wanted to fit Neoplatonic magic into theology by replacing the One with God. Other scholars saw the Kabbalah, a Jewish esoteric tradition, as a helpful device to achieve this. One of these humanists, the Italian Pico della Mirandola (1463-1494), even went so far as to state that there "is no science

13 See Paola Zambelli, White Magic, Black Magic in the European Renaissance (Leiden, 2007).

14 Denis J.J. Robichaud, Plato's Persona: Marsilio Ficino, Renaissance Humanism, and Platonic Traditions (Philadelphia, 2018), 2.

15 A concise elucidation in Lloyd P. Gerson, "Plotinus on Logos," in Neoplatonism and the Philosophy of Nature, ed. James Wilberding and Christoph Horn (Oxford, 2012), 17-29. 
that assures us more of the divinity of Christ than magic and Cabala," a thesis which was condemned by the Church. ${ }^{16}$

In 1517 the Kabbalah was translated from Hebrew into Latin by the German Hebraist Johann Reuchlin (1455-1522), a friend of Pico and one of the first humanists north of the Alps to be heavily involved in natural magic. He was, by the way, also a grand uncle of Melanchthon. Already in 1494 he had published his De verbo mirifico [On the Wonder-Working Word], a study in arcane and occult philosophy. Or as Charles Zika puts it:

The "wonder-working word" of the title, is not merely the instrument of internal mystical union between man and God ... but also the instrument by which man performs external miraculous activities in the world ... This word is a sign of the divine union in so far as it is the source of superhuman activity. ${ }^{17}$

Reuchlin condemned those types of magic that made use of demonic assistance but maintained that the use of words or formulae found in the Kabbalah was permitted to Christians. According to him the sacred name of Jesus, the Pentagrammaton IHSUH, was the real wonderworking word. It "is the instrument of the internal mystical union between man and God, and also the instrument by which man is able to perform external miraculous activities in the world."18

Despite Reuchlin's fame, another German, Agrippa ab Nettesheim, was the best-known magician of that period. During his travels through the German Empire, Italy, Spain, England, France, Switzerland and the Low Countries he acquired an immense learning, gained many admirers, and probably even more enemies, including very powerful ones like the Queen Mother of France. Much has been written about this fascinating man, but the final word has yet to be said. Agrippa knew the work of Reuchlin very well and was deeply influenced by it. ${ }^{19} \mathrm{He}$ had even lectured on the De verbo mirifico in 1509 at the University of Dole. ${ }^{20}$ In 1529 the Antwerp publisher Michael Hillenius Hoochstratanus

16 This sentence has been quoted many times, for instance in Frances A. Yates, Giordano Bruno and the Hermetic Tradition (London, 1964), 112.

17 Charles Zika, Exorcising our Demons: Magic, Witchcraft, and Visual Culture in Early Modern Europe (Leiden, 2003), 24-25.

18 Van der Poel, Cornelius Agrippa (see above, n. 8), 6o.

19 Nauert, Agrippa and the Crisis (see above, n. 8), 129-136.

$20 \quad$ Van der Poel, Cornelius Agrippa (see above, n. 8), 59; Zika, Exorcizing our Demons (see above, n. 17), 67 . 
issued a volume containing a collection of treatises of Agrippa and Reuchlin's De verbo mirifico. ${ }^{21}$

\section{$2 \quad$ Study in Paris and Friendship with Servetus}

It was with this intriguing intellectual luggage that Wier began his studies in Paris in 1533, staying there until 1539. Agrippa's lessons would have enabled him to skip the introductory courses of the arts faculty and go without delay into his major. In 1539 he returned to Grave after having studied medicine in Paris. Despite frequent assumptions about Wier's training, he did not obtain a doctor's degree.

The Parisian medical faculty counted only a few students, about 50 to 100, and we may assume that they all knew each other personally. ${ }^{22}$ So, Wier must have met there another Brabanter, Andreas Vesalius, though the two never became friends. In 1543, Vesalius launched a massive attack on Galenus' anatomy in his De humani corporis fabrica [On the Structure of the Human Body]. Oporinus published this masterpiece of printing technique. ${ }^{23}$ In Paris, Vesalius assisted the professor of medicine Guenther of Andernach in his anatomical seminars until 1536. In the first editions of his De praestigiis, Wier did indeed mention Vesalius, but in an oblique way. ${ }^{24}$ Later he even left out Vesalius' name altogether. It is clear that the two were not close. In a new chapter in 1568 Wier added that Vesalius's successor as Guenther's assistant, Michael Villanovanus, was a close friend of his. ${ }^{25}$ In reality this was Michael Servetus (1511-1153) who, after he had published in 1531 his doubts about the orthodox dogma concerning

21 Henricus Cornelius Agrippa ab Nettesheim, De nobilitate et prcecellentia foeminei sexus ... expositione libri Johannis Capnionis de verbo mirifico ... ([Antwerp]: Michael Hillenius Hoochstratanus, 1529). Cf. Pettegree and Walsby, Netherlandish Books (see above, n. 10), 1: $11 \mathrm{nr}$. 249. Capnio is the Latinization of Reuchlin's family name.

There are unfortunately no matriculation records from the sixteenth century of the faculty of medicine; it is not possible to establish exact totals of the students there. See L.W.B. Brockliss, "Patterns of Attendance at the University of Paris, 1400-180o," The Historical Journal 21 (1978), 503-544, there 515 and 523. For the curriculum of the medical program, see Charles D. O'Malley, Andreas Vesalius of Brussels, 1514-1564 (Berkeley, 1965), $39-42$.

23 Andreas Vesalius, De humani corporis libri septem (Basel: Oporinus, 1543).

24 In 1563,1564 , and 1566 he praised Vesalius as incomparabilis ("outstanding"), in the edition of 1568 only his name appears and in later issues he is not mentioned at all; De praestigiis (1563) (see above, n. 4), 229; (1564), 243; (1566), 297; (1568), 285-287.

De praestigiis (1568), 571 . 
the Trinity, had adopted as a pseudonym the name of his Aragonese birthplace Villanueva in order to avoid both Catholic and Protestant heresy hunters. ${ }^{26}$

Wier and Servetus shared a number of features. The first of the two had been trained in natural magic and Neo-Platonism by Agrippa, while the other one, after he had moved from Paris to Lyon in 1534 to evade a massive hunt for heretics, was introduced to these fields of thinking by the physician Symphorien Champier, an acknowledged expert in that regard. ${ }^{27}$ In 1536 Servetus returned to Paris where he began or renewed his friendship with Wier, as they both studied medicine. Only one year later, in a publication about the medical use of syrups, Servetus attacked Champier and showed that he had already distanced himself from his former mentor and his ideas. ${ }^{28}$ Wier took a similar step, although he only openly said so in 1563 in the first edition of his De praestigiis and it is unclear whether he had reached this viewpoint only then or earlier. ${ }^{29}$ Agrippa, Reuchlin, and Ficino had at one point or another appeared to do the same in renouncing magic. ${ }^{30}$ However, their sincerity in this can be doubted. What they did reject, unlike Trithemius and Paracelsus, was not so much magic in general as unlearned magic. It may be that one of the reasons why Wier so vehemently opposed Paracelsus was that the latter based much of his magic on popular beliefs and practices. ${ }^{31}$ There is therefore a caveat regarding the sincerity of Wier's rejection of magic in general. He must have been aware of the fact that Reuchlin had not really rejected magic, but that did not keep him from introducing this Kabbalist as "the adornment of Germany," a man "very expert on languages" who had shown the falsity of this "superstition."32 This begs the question of how sincere Wier's rejection of magic in overall terms really was.

26 Literature on Servetus is vast; see, for example, Roland H. Bainton, Hunted Heretic (Boston, 1953); Jerome Friedman, Michael Servetus: A Case Study in Total Heresy (Geneva, 1978); A. Gordon Kinder, Michael Servetus [Bibliotheca dissidentium: Répertoire des non-conformistes religieux des seizième et dix-septième siècles 10] (Baden-Baden, 1989).

27 Brian P. Copenhaver, Symphorien Champier and the Reception of the Occultist Tradition in Renaissance France (The Hague, 1978), 78.

28 Ibid., 78.

29 Wier, De praestigiis (see above, n. 4), 110-114.

30 Daniel Pickering Walker, Spiritual and Demonic Magic: From Ficino to Campanella (University Park, 2003), 45-53; Frank Klaassen, The Transformations of Magic: Illicit Learned Magic in the Later Middle Ages and Renaissance (University Park, 2013), 210; Erika Rummel, The Case against Johann Reuchlin: Religious and Social Controversy in Sixteenth-Century Germany (Toronto, 2002), 16.

31 Cf. Zambelli, White Magic (see above, n. 13), 15.

32 Wier, De praestigiis (1563, see above, n. 4), 119. In all the following editions this passage reappeared, albeit with slight changes. 
Be that as it may, whatever the similarities in their ways of thinking, there was at least one major difference between Wier and Servetus as regards religion. Wier had never shown any doubt regarding the dogma of the Trinity as canonized in 325 by the Council of Nicaea. So there is no indication that Wier agreed with the views his new friend had published just a few years before they met. Contrary to what is often thought, in the two tracts he published in 1530 and 1531, Servetus did not deny the existence of the Trinity as such, but stated that the Trinity did not consist of three persons in one but of three dispositions of God. ${ }^{33}$ "Jesus, surnamed Christ, was not a hypostasis [one of three distinct persons of God] but a human being": this was the second sentence of his De Trinitatis erroribus libri vii [Seven Books on the Errors of the Trinity] that appeared in 1530. And a few lines further down: "Careful interpretation of the usual proof-texts show that they teach not a union of three beings in one, but a harmony between them." ${ }^{34}$ In his summary of book II he wrote:

1. Christ, the Son of man, ascended into heaven, and we are in heaven when we believe that he is the Son of God. 2. Christ, the Son of man, came down from heaven. 3. One who sees Christ sees the Father through him. 4. The Word which was in the beginning was simply the utterance which God gave when first creating the world. 5. Christ was thus the voice of God become flesh, and intrusted with the function of speaking for God. 6. It was the Word originally with God, not a second being, that became flesh. ${ }^{35}$

This came very close to the Neoplatonism Wier was, thanks to Agrippa, so familiar with. And what Servetus stated at the end of that part of his treatise came quite close to the spiritualism Wier was to embrace a few years later: "there is in our spirit a certain powerful and hidden energy, a certain heavenly feeling, and a hidden divine something." 36

33 Michael Servetus, The Two Treatises of Servetus on the Trinity, trans. Earl Morse Wilbur (Cambridge, MA, 1932), xiii. An important caveat should, however, be mentioned. Servetus is not always very consistent when discussing the nature of the Trinity, sometimes using formulations that are well in line with the orthodox view. See, for example, Jerome Friedman, Michael Servetus (see above, n. 26), 22-23. Also see Christine Schulte am Hülse's essay in this Special Issue of Church History and Religious Culture.

34 Servetus, The Two Treatises (see above, n. 33), 3.

35 Ibid., 70.

36 Ibid., 104 . 
In 1539, or perhaps 1540, Servetus and Wier went their separate ways and it is unknown if they kept contact after they had left Paris. Wier returned to his birthplace of Grave where he set up a medical practice, married and became the father of four sons and one daughter. In 1545 he moved to nearby Arnhem where he was appointed municipal physician, from where he was called in $155^{\circ}$ to the court of Wilhelm of Cleves, Jülich and Berg to become this Duke's first physician. Duke Wilhelm, nicknamed the wealthy, was already in his own time renowned as a supporter of religious tolerance as he strived in his domains for a middle way, a via media, between Roman Catholicism and Protestantism. Servetus moved back to the region around Lyon, where after a few years as general practitioner he became personal physician to the Archbishop of Vienne, Pierre Palmier.

In 1553 Servetus published his Christianismi Restitutio [The Restoration of Christianity], in which he showed that his thinking had radicalised in the sense that he now held that baptism should be administered to individuals not younger than thirty, the age at which Jesus received this sacrament himself. ${ }^{37}$ This made him susceptible to the accusation of Anabaptism. Combined with his frequent use of rabbinical literature, this gave opponents like Calvin and the Catholic Inquisition the arguments they needed to accuse him of Judaizing. Calvin knew Servetus's pseudonym and via a collaborator of his with a relative who worked for the Inquisition he revealed to this Catholic agency the identity of the author of this "hideous" book. Servetus was then captured; he managed to escape and then decided for some enigmatic reason to go to Geneva. There he was recognised, imprisoned, tried, and in October 1553 burnt alive.

A year after this execution, Sebastian Castellio $\left(1515^{-1563)}\right.$ published his $D e$ haereticis, an sint persequendi [On Heretics, whether they should be persecuted]. Castellio was a former assistant of Calvin who became disappointed by the reformer's intransigence and in 1545 exchanged Geneva for Basel where in 1553 he was appointed professor of Greek, and where he published De haereticis. ${ }^{38}$ This was a collection of texts supporting the necessity of tolerance and a

37 Michael Servetus, Christianismi Restitutio totius ecclesiae apostolicae est ad sua limina vocatio, in integrum restituta cognitione Dei ([Vienne]: [Balthazar Arnoullet], 1553). For more on this source, as with Servetus's earlier work, see Christine Schulte am Hülse's essay in this Special Issue.

38 De haereticis, an sint persequendi, et omnino quomodo sit cum eis agendum, Doctorum virorum tum veterum, tum recentiorum sententiae. Liber hoc tam turbulento tempore pernecessarius, ed. Martinus Bellius [= Sebastian Castellio] (Magdeburg [= Basel]: Georgius Rausch [= Oporinus], 1554). The most complete biography of Castellio still is Ferdinand Buisson, Sébastien Castellion, sa vie et son oeuvre $\left(15_{15}^{-1563)}\right.$ (Paris, 1892$)$. On De haereticis, see ibid., $360-413$. 
fierce protest against Calvin's lack of that quality. According to the title page, it was edited by a certain Martinus Bellius and printed in Magdeburg by a publisher named Georgius Rausch. In reality, it was Castellio who was behind it and Oporinus who printed the book in Basel. One of the authors who contributed to De haereticis was the Dutch spiritualist prophet David Joris (ca. 1501-1556). ${ }^{39}$ Both Castellio and Oporinus were in close contact with him, as was Johan Wier.

\section{3}

\section{Oporinus}

In 1543, Oporinus had set up his publishing firm and one of the first books he printed was the famous atlas of the human body of Vesalius. This typographical masterpiece immediately established his reputation. At that same time he brought out the first printed edition of the Koran and a book by the French spiritualist Guillaume Postel. ${ }^{40}$ He printed several of Postel's works with the financial support of David Joris, who was at that time living in Basel. He also printed the Latin and French Bible translations of Castellio that annoyed Calvin and Beza so much that they scolded Castellio, the "chosen instrument of the devil." In 1557 Oporinus also printed Castellio's Latin translation of the Theologia Deutsch, a mystical work that has influenced many spiritualists, among them Matthias Wier, the youngest brother of Johan who acted as a guide in this field. In 1563 Oporinus released Johan's book on the tricks of demons.

Oporinus was, we can say, a trusted figure among spiritualists. It is uncertain whether he personally sympathised with their thinking but he was certainly respected by some of them, including Joris. A letter dated 1 September 1561 by Caspar Schwenckfeld (1489/9o-1561) is in that regard illustrative. In it the spiritualist prophet asked the printer-publisher if it was true that scholars in Basel accused him, Schwenckfeld, of heresy and if this could pose a threat to him. ${ }^{41}$

39 On this see Mirjam van Veen, “'Contaminated with David Joris's Blasphemies': David Joris's Contribution to Castellio's De haereticis an sint persequendi," Bibliothèque d'Humanisme et Renaissance 69 (2007), 313-326.

40 Harry Clark, "The Publication of the Koran in Latin: A Reformation Dilemma," The Sixteenth Century Journal 15 (1984), 3-12. On Oporinus's role as printer-publisher of the works of spiritualists like Castellio and Postel, see Peter G. Bietenholz, Basle and France in the Sixteenth Century: The Basle Humanists and Printers in their Contacts with Francophone Culture (Geneva, 1971), 122-144.

41 Martin Steinmann, "Aus dem Briefwechsel des Basler Druckers Johannes Oporinus," Basler Zeitschrift für Geschichte und Altertumskunde 69 (1969), 103-204, there 168-169. 


\section{Spiritualism and Johan Wier}

In January 1573 Thomas Erastus (1524-1583), professor of medicine at Heidelberg University and first physician to the Reformed Elector of the Palatinate, wrote to Heinrich Bullinger (1504-1575), the Zurich leader of the Zwinglian Reformed, about Johan Wier: "I hear [that he is] contaminated by the error of Schwenckfeld." ${ }^{2}$ Erastus was without doubt well informed about his colleague, the first physician to the Duke of Cleves, Jülich and Berg. A few years earlier Wier had inspired Erastus to join him in a vehement rejection of Paracelsus's medical ideas and they both fully endorsed Galenus's physiology and pathology. 43

But it was not in 1573 that Wier finally took up his interest in spiritualism. Actually, it was at the latest in the 155 os that he did so. When in October 1566 his oldest son Theodore applied for a nomination as councillor in the Court of Justice of the province of Gelderland, Margareta of Parma, half-sister of King Philip II and vice-queen of the Low Countries, asked the Court for information regarding his religious background. The Court replied that as far as they knew Theodore was a faithful Catholic, although "as regards religion his father and mother are a bit suspect." ${ }^{44}$ So Johan and his wife Judith were not faithful devotees of the Church of Rome, but it remains unspecified whether they perhaps supported another confession. But then it is also true that it would have been very difficult to do so. In 1578, Wier wrote in the foreword to the adaptation of his De praestigiis for a German-speaking public:

So the situation is now thus that nobody in his own adopted religion can put up with another person who is not willing to share his opinion (even though he is quiet, friendly and nice, not rebellious, but God-fearing). And there is actually no discord regarding the central tenets of our Christian belief, but only regarding form or time, or some change in the ceremonies or religion or words, or anything that does not affect the true and sincere belief. $^{45}$

42 As quoted in Charles D. Gunnoe, Thomas Erastus and the Palatinate: A Renaissance Physician in the Second Reformation (Leiden, 2011), 348.

43 Ibid., 277-279.

44 Gelders Archief in Arnhem, Archive 0124 (Hof van Gelre en Zutphen), inventory number 658; edited in Bijdragen voor Vaderlandsche Geschiedenis en Oudheidkunde, ed. Isaac A. Nijhoff, 10 vols. (Arnhem, 1848), 6: 266-270.

45 Johan Wier, De praestigiis daemonum: Von ihrer ursprung, underscheid, vermögenheit, und rechtmessiger straaff, auch der beleidigten ordenlicher hilff, sechs Bücher (s.l., s.n., 1578), 
So in 1578 , Wier sincerely disliked the fragmentation of Christendom and he had distanced himself from the Church of Rome, but he was not willing to join any of the Protestant confessions either. In the same introduction he stated:

So like the people from Nineveh we do not expiate our sins. We do not confess our guilt, for we are so pious, we are Evangelical, we are this and that, while we wish to make ourselves guiltless and clean. Therefore we do not call on God, so that he will not use against us his rot, plague, or sword, what we hold to be true, but instead one throws money and wealth in the offertory-box, and consequently looks elsewhere for help and deliverance, takes refuge with cunning folk, grabs the old women, turns them into a burnt offering, then master Hans [the executioner] can alleviate the thunderstorm with fire, and avert all misfortune. ${ }^{46}$

There are two remarkable elements in this diatribe. People who denied their sins could be of all sorts, but there were certainly also Protestants among them. And the second is where he reproached people for not showing any remorse for their sins, simply throwing some money in the collection box. Mind you, this is exactly the practice that inspired Martin Luther to rise up against the Church hierarchy. What Wier showed here is pure disdain for hypocritical Protestants.

In the foreword to his Artzney Buch, the translation of his medical casebook Medicarum observationum rararum [Of Rare Medical Observations], he wrote in 1580:

But who does penance for his sins and repents, or wishes to urge other people to do so, is ridiculed and derided, and with disdain called either a Carthusian, a Zwinglian, an Anabaptist, or a similar despicable something. And, what is really the worst, someone who in order to avert the penalties for the sins mentioned above, and is, what is only fair, punished by God with an illness, commits a capital crime in that he will sooner ask the devil for help, than turn to God, and against God's explicit ban gives credence more easily to cunning folk, sorcerers, people who give blessings, and similar scum, than to devout and experienced physicians. ${ }^{47}$

dedication to the Burgomasters and Council of the city of Bremen, iijr-v. The translation is mine.

46 Ibid., ivv. The translation is mine.

47 Johan Wier, Artzney Buch: von etlichen bisz anher unbekannten unnd unbeschriebenen Kranckheyten (Franckfurt a. M.: Nicolaus Bassaeus, 1580), xiii. 
This is clearly a reflection of his personal experience. The Carthusians of course stand for pious Catholics, the Zwinglians for similar Reformed and Anabaptists for pious Mennonites. It is remarkable that Lutherans and Calvinists remain unmentioned here. Catholics, Zwinglians, Mennonites can all be very pious, but there is a suggestion that when it came to piety Lutherans and Calvinists were of a lower status.

So what should people who consult devout and experienced physicians do? The quotations given here show clearly what Wier did not like, but not so much the contents of his personal convictions. He, however, gave hints at other places. In the introduction to that same Artzney Buch he also wrote:

So all that has been said above leads to the conclusion that who wishes to stay healthy and well, should as mentioned be unwilling to give cause for unhealthiness. Who does not want to be punished with older illnesses should get rid of the old Adam. Who wants alleviation of his relief of his weakness should break off from his sins.

So, we should, according to Wier, liberate ourselves from the old Adam and that is a clear reference to the spiritualism of prophets like David Joris who held that with the Fall the inner senses of man had lost the ability to perceive God. ${ }^{48}$ A reorientation of the senses would set us free from the post-Fall Adam and restore the pre-Fall direct contact with God. All people should follow their own individual paths to this restoration and nobody had the right to force others in one direction or the other. Thus, tolerance was granted.

\section{$5 \quad$ The Wier Family}

At the age of about fourteen Johan was, as already mentioned, sent to Agrippa. His father's choice of this humanist as teacher for his son was remarkable. Agrippa was a very learned humanist, but also a controversial figure and it may be assumed that Johan's father was aware of that. Apparently he did not perceive that as a problem, and neither did he oppose his son's decision in $153^{2}$ to follow Agrippa to Bonn. His mentor had run into serious problems with the court of the vice-queen in Brussels and the theologians of the University of Leu-

48 Gary Waite, David Joris and Dutch Anabaptism, 1524-1543 (Waterloo, on, 1990), 211-212. See also Waite's essay in this Special Issue. 
ven and decided to move to Bonn where the archbishop of Cologne was willing to let him stay.

Other members of the Wier family also sympathized with unorthodox libertarian views. Johan had two younger brothers, Arnold and Matthias (1521-156o), and one sister, Elisabeth. Matthias was himself a spiritualist guide, but unlike David Joris or Hendrick Niclaes (ca. 1502-ca. 1570) he never claimed that God had chosen him as his mouthpiece to transmit his messages ${ }^{49}$ After his death in 156o his friend and pupil Pieter de Zuttere of Ghent published a thematic version of his letters and sayings in $1563 .{ }^{50}$ Sixteen years later a systematic edition in Dutch was printed, probably edited by Johannes Spee, also a former pupil of Matthias. ${ }^{51} \mathrm{~A}$ German version appeared in 1633 , and an English one in $1683 .{ }^{52}$ Quotations here will be from the latter of these two. In 1658 the German translation was re-issued in Amsterdam by the publisher / printer Henricus Betke who finally also produced a Latin edition. ${ }^{53}$ Betke brought out an impressive number of similar works by authors like Jacob Böhme. His printing activities certainly gave a major impetus to German Pietism. ${ }^{54}$

49 On him see Gary K. Waite, "Demonic Affliction or Divine Chastisement? Conceptions of Illness and Healing among Spiritualists and Mennonites in Holland, c. 1530-c. 1630," in Illness and Healing Alternatives in Western Europe, ed. Marijke Gijswijt-Hofstra, Hillary Marland, and Hans de Waardt (London, 1997), 59-79; Piet Visser, "Zeldzame mennonitica: Een liedboek uit 163o, een herdruk van Matthias Weyer en het werk van de onbekende Popken Wierts," Doopsgezinde Bijdragen 20 (1994), 241-247; Gwendolyn Verbraak, De lijdensweg van een 16e eeuwse mysticus: Een onderzoek naar mystieke en protestantse denkbeelden in het werk van Matthias Weyer (ca. 1521-156o) (MA diss., University of Amsterdam, 2004).

$5^{\circ} \quad$ [Matthias Wier], Eyn kort Bericht um to kommen tot den waren Gehoor dess levendigen Woirdtz Gotz, vnde so tot die Erkentenisse vnde Vrymakunge van die wesentlicke Waarheyt, dör sterven vnde vnderganck vnser gantzer Naturen ... ([Wesel]; [Pieter Anastasius de Zuttere], 1563). A meticulous survey of the editions of Matthias's texts is in Verbraak, "De lijdensweg" (see above, n. 49), 97-117.

51 [Matthias Wier], Grondelicke Onderrichtinghe, van veelen Hoochwichtighen Articulen, eenen yeghelijcken die tot Reyniginge zijnre Sunden, ende in die wedergheboorte begheert te comen, seer dienstelijck ... (Francfurt [= Amsterdam]: [Harmen Jansz Muller], 1579).

$5^{2}$ Matthias Wier, Gründlicher Unterrichtung Von Vielen Hochwichtigen Articuln, einem jeden der zur reinigung seiner Sünden, und in die Widergeburt begehret zukommen, sehr dienstlich ... (Frankfurt:Johann Fridrich Weiß, 1633); Matthias Wier, The Narrow Path of Divine Truth Described From Living Practice and Experience of Its Three Great Steps (London: Ben. Clark, 1683).

53 Matthias Wier, Gruendliche Unterrichtung von vielen hochwichtigen Articuln ... (Amsterdam: Henricus Betke, 1658); Matthias Wier, Theologiae mysticae triumque illius viarum, purgativae, illuminativae atque unitivae ... (Amsterdam: Henricus Betke, 1658).

54 W. Heijting, "Hendrick Beets (1625?-1728), Publisher to the German Adherents of Jacob Böhme in Amsterdam," Quaerendo 3 (1973), 250-28o. 
Several of Matthias's letters were destined for relatives, six of them for his and Johan's brother Arnold, four to Johan himself, two to their sister Elisabeth, two to a niece, and one to an uncle. ${ }^{55}$ The last was only identified by his initials M.D.W., Johan is in the headings of three of the four letters identified as J.W., and Arnold as A.W. Their sister is indicated as "A," although her name was, as we will see, Elisabeth. The letters are in chronological order, although only two of them bear some sort of date. The uncle's letter was sent in the year $155^{2}$ and the final letter, to his sister, was sent "the ninth day before his death." According to a note added after this last letter he "died in the Lord 25 April in the year of our Lord 156o and of his own age the 39." In the letter to his uncle Matthias writes amongst other things that he and his mother are well, although his own health does not appear to be very sound. Actually, references to his physical weakness are frequent in the correspondence with his relatives. The last eight letters are all about his failing health and seven of these are destined for "My brother" without further indication of the name of this relative. Considering that Johan was a physician it is not unlikely that he was the recipient, but nothing final can be said in that regard.

The physical state of Matthias is a major theme in his correspondence but is of course not the central subject, which are his religious views. His main subject is the sort of life a good Christian must lead in order to attain salvation. Unlike prophets like Joris or Niclaes he did not hold that human beings could merge with God already during their life on earth. That only happened after death and only after a deeply pious and ascetic life of endurance, self-denial and hardship. Actually, there was little difference between Matthias's model and that of medieval mystics. He does indeed repeatedly refer to the teachings of the Dominican mystic Johannes Tauler (ca. 1300-1361). This places Matthias in a line of Neo-Platonist mystics like the Dominicans Eckhart (ca. 126o-1328) and Heinrich Suso (1295/97-1366) whose vernacular sermons and tracts were widely read in the fourteenth century and later ${ }^{56}$ In the sixteenth century, Tauler was claimed by Protestants like Luther but also by Catholics like Petrus Canisius. It should, however, be added that this approach was not the general attitude on either side of the confessional dividing line and that in order

55 Wier, The Narrow Path (see above, n. 52), 431-440, 441-444, 449-451: nrs. 23-27, 30, to Arnold Wier; 398-402, 419-431, 446-449: nrs. 17, 21, 22, 29, to Johan; 371-376, 467-468: nr. 10, and the unnumbered final letter to Elisabeth Wier; $359-371$ : nrs. 8 and 9 to a niece; 392-398: nr. 16 to uncle M.D.W. The English version erroneously translates the Dutch word oom which means "uncle" as "Cosin."

56 James M. Clark, The Great German Mystics: Eckhart, Tauler and Suso (Mineola, NY, 2013), 1,6 , and 18 . 
to enlist him his sympathizers had to spirit away parts of his writings and actions. ${ }^{57}$ So, to what extent were the thoughts of these mystics in conformity with Catholic orthodoxy? Eckhart, for instance, was posthumously convicted of heresy and Church authorities also often distrusted other mystics. As Julia Lamm concludes in her survey of Christian Mysticism: "it is by no means a foregone conclusion that any given mystic will have faced suspicion about his or her orthodoxy."58 So to what degree was Matthias a Protestant? He was, one could say, in the sense that in his eyes the Church of Rome had perverted the message of Christ and that the Pope was Antichrist. But it could also be maintained that he was at least a sort of Catholic in the sense that he held that humans had to earn salvation by the quality of their life on earth. There is in his sayings or letters no talk of the Lutheran "by faith alone," and even less of the Reformed predestination. People had to restore Adam in themselves and thus find the road, which was anything but easy, to earn admittance to heaven:

He that rightly knows the fall of Adam and understands his restauration cannot rejoice, because a man must perish for its sake, and as to all these things he must be annihilated, as to what he is made for. Gladness is assigned over to posterity, and to that fruit which shall grow out of corruption, where a man becometh to be that, which he attaineth to out of corruption. And then he appeareth in the glory of God, and acknowledges God from God, and loves God from God, and is sanctified, and justified, and renewed in God. And he is made that by grace, which God is by nature. ${ }^{59}$

It was not only Tauler that linked him to medieval mysticism. He acknowledged also the Imitatio Christi and especially the Theologia Deutsch as important sources:

The small treatise of the Imitation of Christ is very useful to them that are labouring and striving, for it giveth us the best instruction unto life, and I am much delighted therewith, but the German Divinity excelleth, in which is the representation of God. The book of the imitation is more

57 Ibid, $49-5$ o.

58 Julia A. Lamm, The Wiley Blackwell Companion to Christian Mysticism (Hoboken, 2017), 100.

59 Wier, The Narrow Path (see above, n. 52), 142-143. 
profitable for the publick, but the small treatise of the German Divinity is for private use. ${ }^{60}$

There were many editions available of the Imitatio Christi, the devotional handbook written about a century earlier by Thomas a Kempis (1379/8o-1471), a prominent member of the Devotio Moderna who had composed his Imitatio in Zwolle. As a spiritual guide his book was popular among both Catholics and Protestants, although the latter for evident reasons always left out the fourth part that sang the praise of the Catholic communion. It is impossible to decide which edition Matthias used, but it may have been the German version that Schwenckfeld published in $1531 .{ }^{61}$ This version was well known and was sold in large numbers. In a letter with medical advice he may have sent in October 1583 to the Countess of Berg, who was a sister of William of Orange, Johan Wier deplored that he was not able to send her a copy of the De imitatione. ${ }^{62}$ This suggests that he believed that besides drugs, devotional, in this case spiritualist, literature could help patients to restore their health.

According to Matthias the Imitatio was a useful book but of prime importance was the Theologia Deutsch, the mystical handbook that was printed for the first time in 1516 in an abridged version and in 1519 in a full edition by Martin Luther, who erroneously believed Tauler to be its author. ${ }^{63}$ Together with the works of Tauler, this book was of great influence in Germany among people with a spiritualist interest. In his authoritative The Radical Reformation, George Williams considers the sermons of Tauler and Theologia Deutsch parts of what he terms the Deutero-Taulerian Corpus: the synthesis of earlier medieval forms of mysticism that lived on after the Reformation. ${ }^{64}$ Other editions followed

\footnotetext{
6 o Ibid.

61 Maximilian von Habsburg, Catholic and Protestant Translations of the Imitatio Christi, 1425-1650: From Late Medieval Classic to Early Modern Bestseller (Farnham, 2011), 107-114. One of the people who were influenced by it was Castellio, who in 1563 published a revised Latin edition of De imitatione. For evident reasons it is impossible that Matthias had consulted this version as he had passed away three years before it was printed.

62 Original in the Erfgoedcentrum Achterhoek en Liemers, access nr. o214, inventory nr. 445, nr. 8oo1; edited in L. Dooren, Doctor Johannes Wier: Leven en werken (Aalten, 1940), 143.

63 Eyn geystlich edles Buchleynn. von rechter underscheyd vnd vorstand, was der alt vn $[d]$ new mensche sey. Was Adams vnd was gottis kind sey. vn $[d]$ wie Ada $[m]$ ynn vns sterben vnnd Christus ersteen sall, ed. Martin Luther (Wittenberg: Rhau-Grunenberg, 1516); Theologia Teütsch. Das ist ain edels und kostlichs büchlin, von rechtem verstand, was Adam und Christus sey, und wie Adam in uns sterben, und Christus ersteen soll, ed. Martin Luther (Strasbourg: Knoblouch, 1519). Cf. George Huntston Williams, The Radical Reformation, 3rd ed. (1962; Kirksville, MO, 2000), 77-78.

64 Williams, The Radical Reformation (see above, n. 63), 79-82.
} 
Luther's, such as Schwenckfeld's of 1531. Under a pseudonym Castellio published a Latin version: Theologica Germanica, in 1556 in Antwerp with Plantin and a year later in Basel with Oporinus.

In his correspondence Matthias also discussed the views and activities of some other spiritualist mentors like the leader of the Family of Love, the prophet Hendrik Niclaes. Acquaintances of his had provided Johan with publications of Niclaes and he had sent these to his brother. Matthias's verdict on Niclaes's teachings was harsh. In the first letter to Johan about them, he stated: "the opinion of the writer is contrary to my mind, because it consisteth in the knowledge only of a seeming divine truth, and not in an essential truth of God." He then asked his older brother to keep a keen eye on the people who had given him these writings, clearly to check whether their way of live was in accordance with the precepts of their leader. ${ }^{65}$ In a letter to their brother Arnold, Matthias could then impart that Johan "was here, and hath utterly and cordially renounced the thing its self, because he had experienced \& found from their presence, that they were infected with the venome of carnal liberty and that all issued out of that fountain." 66 In other words, Johan had observed that the people who had joined the Family of Love were not pious but inclined to material matters. A little earlier Johan had sent him a copy of "a little book of Diederick Phillips ... concerning the New Creature," and asked him for his opinion. In his review Matthias was a bit milder than in his assessment of Niclaes' work, but certainly not unequivocally positive. ${ }^{67}$ The problem for him was that Phillips believed that mortals even before their bodily death could attain the status of a new creature. Matthias pointed out that as long as he was still on earth a human being could fall back into sin. Only through death could he reach that status, or as he put it:

To be subjected on the cross, to the obedience of God, by the means of pouring forth of the blood of Christ Jesus our Lord; into whose communion we are taken by a like death, according to the inward man, so that on

65 Wier, The Narrow Path (see above, n. 52), 424-431.

66 Ibid., 433. Matthias was referring to a publication by Menno Simons's assistant, Dirk Philips, Vande wedergeboorte ende nieuwe creature: Een corte vermaninghe ende aenwijsinghe uut de Heylighe Schrift ([Emden]: [Steven Mierdmans], [ca. 1556]). On this letter of Matthias, see also Sjouke Voolstra, "Innerlijk en uiterlijk vertoon van Christus: De verhouding tussen spiritualisme en doperdom toegelicht aan de hand van de reactie van Matthias Weyer (1520-1561) op een traktaat over de wedergeboorte van Dirk Philips (1504-1568)," in Beeldenstormer uit bewogenheid: Verzamelde opstellen van Sjouke Voolstra, ed. Anna Voolstra, Alle G. Hoekema, and Piet Visser (Hilversum, 2005), 91-103.

67 Wier, The Narrow Path (see above, n. 52), 419-424. 
the cross we wholly put off our natural life which we had in the flesh, being buried with Christ, and afterwards raised up again into another supernatural life. ${ }^{68}$

Niclaes made that same mistake according to Matthias. He had been on the right track, but had then fallen for the temptation of the carnal, that is the material world.

In his emphasis on the necessity of going through a death on the cross in order to imitate Christ, Matthias came close to David Joris's view that humans had to pass through that passion in order to attain unification with God. Matthias here uses that image, as well, but with two major differences: for him this fusion is only possible by passing through physical death, whereas Joris held that it was already possible during life on earth, ergo before bodily death. And secondly, for Matthias it was necessary to really suffer, whereas Joris saw the process more as a mystical, perhaps mentally difficult, but not physically painful, phase one had to go through to retrieve the remnants of the Adam from before the Fall.

\section{6}

\section{Johan, Matthias, and David Joris}

In 1544 Joris had fled the Low Countries and moved to Basel where, thanks to the financial support he received from his followers, he could lead a fairly easy life until his death in 1556. In Basel he adopted the pseudonym and title Junker Johan von Brügge. From there he kept contact with his followers by sending them numerous letters. Early in the seventeenth century a large collection of these were published in Delft in four parts. ${ }^{69}$ One of these is a letter he sent in April 1556, only a few months before his death in August, headed "Written in friendship [inspired by the] simplicity of Godly attention, to Master Matthias, together with Master Jan, and the pious, faithful and sincere people you know in Paris." ${ }^{70}$ The first addressee of this letter is clearly a Matthias, who had asked Joris for written advice and had also visited him in Basel. But now he was reject-

\footnotetext{
68 Ibid., 423.

69 [David Joris], Christlijcke Sendtbrieven. Inholdende seer veele unde verscheydene schoone Godtlijcke Vermaninghen unde Onderrichtinghen op alderley vragen und anvechtingen, so tot deser tijt den Mensche moghen bejegenen, 4 parts ([Delft]: [Jacob Cornelisz Vennecool], [ca. 160o]).

70 "Meester Matth. sampt Meester Jan, unde die ghy vroom, trouw unde oprecht kent, tot Parijs." Ibid., part. 4, fols. 7or-72r, nr. 63 .
} 
ing the truth as Joris was offering it to him and behaved like a stubborn mule that refuses the good hay that his master is giving him. Joris showed himself to be amazed and upset by this posture. He was not angry, but sad. The family name of these masters Matthias and Jan, a short version of Johan, is not given, but the attitude of the Matthias who figures in this letter is well in line with that of the youngest Wier brother. Towards the middle of the 155os Matthias Wier began to present himself as an independent spiritualist teacher - not as a prophet. If he had until then acknowledged Joris as his mentor, by 1555 a breach between them was unavoidable. It is therefore likely that it is the two brothers Wier whom Joris is addressing here. And as to the pious people the letter is also meant for, it should be remembered that Johan had lived in Paris for about six years and had made a number of close friends there, proof of which is that in the 1568 edition of De praestigiis, he gave a list of them, but also published poems for four of them some thirty years earlier. ${ }^{71}$ When referring to the people Matthias and Jan knew in Paris, Joris appeared to be thinking of personal acquaintances of the two addressees who were not part of his own network. Joris was himself in contact with other people in Paris with whom he corresponded on his own behalf. ${ }^{72}$

A year earlier, in 1555, Joris sent a letter to a "Johan, chyrur[gus] van Cleef," so to a surgeon named Johan who lived in Cleves. ${ }^{73}$ Gary Waite has suggested that this was actually Johan Wier. Joris had received a letter from Johan and in this

71 Wier, De praestigiis (1568), 571. As to the poems see François Bonade, Monodiarum illustrium aliquot personarum Veteris et Novi Testamenti (Angers: [publisher unknown], 1537; and Paris: Simon Colines, 1538), fol. 96v, poem for François Bonade; Gerardus Faber, Oratio exhortatoria ad Ecclesiarum rectores habita Silvanecti (Paris: [Vivant Gaultherot], 1538), poems for Gerardus Faber of Cahors; François Bonade, Ad augustissimam pacis dominam Leonoram Franciae reginam Pathelugentis ecclesiae ad Jesum Christum sponsum (Paris: Simon Colines, 1539), fol. 14r, poem for Jean Vernet, fols. 46r-48r, poem for Vitalis Besumbaeus.

72 The next two letters in Christlijcke Sendtbrieven (see above, n. 69), part 4, fols. 7or-74r, nrs. 64 and 65, are addressed to a person identified as "Kost in Paris" and to a "Master

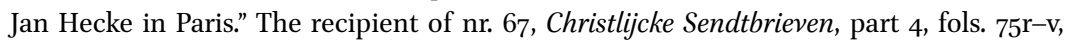
is a lawyer named "Piere Pillet in Paris." Joris's contacts in France are worth researching in more detail; a first start is Eugénie Droz, "Sur quelques traductions françaises d'écrits de David Joris," Het Boek 37 (1965-1966), 152-162. See also Mirjam van Veen, “'Ontallijcke brieven van eenderley materie': De propaganda van David Joris," Doopsgezinde Bijdragen 32 (2006), 39-74, there 62-64.

73 Gary K. Waite, "Radical Religion and the Medical Profession: The Spiritualist David Joris and the Brothers Weyer (Wier)," in Radikalität und Dissent im 16. Jahrhundert / Radicalism and Dissent in the Sixteenth Century, ed. Hans-Jürgen Goertz and James M. Stayer (Berlin, 2002), 167-185. The quotations in this paragraph are from [David Joris,] Het derde Boeck der Christelijcker Sendtbrieven (s.l., s.n., 1611), part 1, fols. $49 \mathrm{v}-51$ r. 
case he also showed himself to be disappointed. "Let no one pride himself on or have a high opinion of himself when one or two scales have fallen from his eyes, that he has then immediately received his right sight or its reinstatement," he wrote. "No, or no," he continued, "these scales or the skins of our meat (in, with and by our eyes are darkened and clouded) are like the hairs on our head that for a short time be enlightened by our Lord Christ in a meek, humble, wellmeaning soul and subservient heart to the right innate Faith of Christ, and in enduring the inner cross of God's grace be taken away," but only in people who obeyed the Word. This word may be God's word, but it had to be accepted in the interpretation of Joris. Joris deplored the fact that Johan now, even though he was well under way to reach the final goal, had decided to change his course. This again is well in line with the development that Johan Wier underwent in these years under the guidance of his brother.

It is quite possible that this letter, like the other one, was meant for the Wiers. The fact that Johan was addressed as a surgeon and not as a medical doctor only shows that Joris knew details of the life of the addressee. Johan Wier never obtained a doctorate and Joris would have heard about this detail from his physician Jean Bauhin of Amiens, who must have known Wier personally. Like Wier, Jean Bauhin had studied medicine in Paris in the 153 os and left France after having been arrested on suspicion of heresy. Thanks to an intercession by the King's sister Marguerite d'Angoulême he was released after which he left the country, first to Antwerp and then to Basel. There he became a close friend of Castellio with whom he shared a house, and he also met Joris there, whose personal physician he became. ${ }^{74}$ Given the restricted numbers of students of medicine in Paris at that time Bauhin would have known Wier personally.

It may be assumed, I think, that the two letters just discussed were sent to Johan and Matthias Wier. Even scholars who do not find this acceptable will accept that the correspondence between Johan, Matthias and their brother Arnold is proof enough that in the 1550s the three brothers were deeply involved in spiritualism. If it is accepted that Johan and Matthias were also corresponding with Joris, their development can be tuned a bit finer. Johan and his youngest brother were initially following Joris, but not long before the middle of the 155 os decided to distance themselves from this prophet. They now also rejected the leadership of other spiritualist mentors like Niclaes or Philips, although later, after the death of Matthias, Johan did accept Schwenckfeld as an inspirational source. 
As noted above, as a boy in his teens Johan was sent to Antwerp to live there with Agrippa, a very learned, but also rather unconventional scholar. A quarter of a century later Wier did more or less the same with his eldest sons. He had four sons and one daughter; the eldest three, Theodore, Hendrik, and Galenus were almost certainly born between 1540 and 1545 when Johan and his family were living in Grave. This may also have been the birthplace of his daughter Sophia and his youngest son Johan Jr., although this fourth boy appears to have been much younger than his three brothers. Anyway, in one of his letters Matthias thanked a certain Justus Velsius (c. 1510-after 1581) for accepting his young nephews as pupils. ${ }^{75}$ Velsius was born in The Hague in Holland, studied medicine and classical languages in Leuven and got a degree in medicine in Bologna. He briefly taught at the academy of Johann Sturmius in Strasbourg and at the newly founded gymnasium in Cologne. In both these towns, one Protestant, the other Catholic, he made longer stays impossible by defending views that were unacceptable for either of the two city authorities. In Cologne he went so far as to publish in 1554 his Krisis in which he stated that true education was unavailable now because the universities were controlled by sophists. It was especially the professors of theology at the University of Cologne who felt offended by this diatribe. Velsius was fired and ordered to leave the town, which he refused to do, so he was arrested and spent the winter of $1555 / 56$ in a dungeon. There he had a vision in which God appointed him as his special guardian and warrior. On 24 March 1556 the authorities of Cologne finally ordered to put him on a boat and moved him to the other side of the Rhine where he was left on the river bank in the domain of the Duke of Cleves, Jülich and Berg. Matthias's letter to him must have been sent shortly after this.

Johan Wier too had been corresponding with Velsius when he was still in jail and it is clear that it was his sons that were now sent to this indeed very learned but also highly eccentric man. In letters to Castellio and Melanchthon, Velsius sang the praise of the Duke's physician. He also corresponded with Joris and Schwenckfeld mainly to impress upon them that they were wrong and he was

75 Wier, The Narrow Path (see above n. 52), 402-409. A rather funny mistake is made in the translation. Whereas the Dutch original has Matthias saying that he hoped "that the Lord will deliver my nephews to you dear sir," the translation has it: "Also I hope that my Uncle will deliver them to you." It is clear that the interpreter did not understand the Dutch abbreviation "U.L." which simply means "dear sir," and translated it as Uncle. On Justus Velsius see Hans de Waardt, "Justus Velsius Haganus: An Erudite but Rambling Prophet," Exile and Religious Identity, 1500-1800, ed. Jesse Spohnholz and Gary K. Waite (London, 2014), 97-109 and 223-227. 
right and this in such abusive language that both prophets broke off all further contact. In September 1556, he was in Frankfurt where a public debate of two days was staged between him and Calvin (who happened to be there as well) about free will and predestination. Velsius contended that "either there is free will, or God is a tyrant." Calvin believed his opponent to be insane. In letters to other people, both these gentlemen claimed a victory. Matthias Wier disapproved of both views:

My opinion is, that Velsius did stumble therein, whilst he attributed too much to the power of man, for humane power is judged and condemned by the Lord, if it be before a man is made partaker of the divine birth, because what is new born is of God, and not of man, it is eternal and immortal, even as he is who begat it. But on the contrary Calvin failed in that point wherein he rejected all the powers of man universally, which indeed I allow to be true, unless that I also judge that knowledge which lieth in man, and convinceth him, doth yet partake of reason and humane power, although the Lord doth afterwards offer to the heart the light of the Gospel, and the understanding of a man submitteth it felt to that. ${ }^{76}$

Velsius, he believed, was too radical in his claim that each human being was of himself capable of choosing the right way, but Calvin erred in that he denied man the possibility to earn grace from the Gospel. The death of Christ offered him this option: "because of the communion he hath received with the death of Christ, [he] is also again raised up by the same Spirit of Christ, so as the Spirit of Christ thenceforward becometh his life, his own reason and all his own powers abiding in death, nor is there a Soul living in him, but by the virtue of God." Calvin failed to see this because he was "not yet dead to his own reason \& strength, he indeed bore witness against his own self." Matthias clung to the tenet he had impressed already many times: "yet still we are to be made liker unto Christ, and to be planted into his death. Furthermore, I here further acknowledge, that no man by the strength of Nature, derived from Adam, can ever attain unto the eternal grace of Christ."

It may be doubted whether Theodore, Hendrik and perhaps also Galenus Wier stayed long with Velsius as this mentor led a highly irregular life. In the course of the following years he moved from one Protestant town or region to the next, only to be kicked out, often within days after his arrival, mainly

76 Wier, The Narrow Path (see above, n. 52), 414-419, letter 20 to A.G. All remaining quotations in this paragraph are from this source. 
because he habitually verbally abused local pastors during Sunday services and organized seminars where he discussed his own religious views that were anything but in accordance with any of the Protestant creeds. But what matters here is that Wier deemed it a good idea, at least initially, to engage this quarrelsome but still very erudite man as teacher for his sons, just as in his case Agrippa had been taken on.

Another indication of Wier's spiritualist sympathies is that in 1561 he married off his sister, who in the relevant sources appears as Elisabeth, to a friend and admirer of Castellio. Charles Utenhove came from a prominent family from Flemish Ghent but had left his hometown for religious reasons. ${ }^{77} \mathrm{He}$ himself in 1528-1529 had lived with Erasmus in Basel and in the 1550s he sent the sons from his first marriage to that same town to study at the university there. The oldest two immediately took up lodgings with Castellio, the third one followed them there a little later. ${ }^{78}$ In Ghent Utenhove was at that time the central figure in a group of humanists who worked hard for tolerance. After Castellio's death in 1563, Johan's brother-in-law acted as one of the guardians of his friend's children, then still under age. ${ }^{79}$

Hidden Messages

It is not only the forewords and introductions to his translations where Wier inserted messages about his religious inspiration. As already noted, as the editions of his De praestigiis appeared one after the other, he inserted small messages in the text, encoded signs, such as the reference to Reuchlin as the authority who had brought down natural magic. Mentioning Servetus as Villanovanus was for the good reader another sign of his sympathies. I will give just one other example here. ${ }^{80}$ In 1568 Wier added a long quotation from an apology of Erasmus against the Spanish Inquisition. ${ }^{81}$ Erasmus had interpreted the parable

77 Willem Janssen, Charles Utenhove, sa vie et son oeuvre (1536-16oo) (Maastricht, 1939), 14 and $97-98$.

78 Ibid., 4 and $17-19$.

79 Buisson, Sébastien Castellion (see above, n. 38), 273; Janssen, Charles Utenhove (see above, n. 77), 15 .

8o For more examples see De Waardt, "Witchcraft, Spiritualism and Medicine" (see above, n. 3), $383-386$.

81 De praestigiis (1568), 625-633. The quotation is from Desiderius Erasmus, Apologia adversus articulos aliquot per Monachos quosdam, in Hispanijs, exhibitos, 2nd ed. (Basel: [Thomas Wolfius], 1529), 89-99. The title itself, "Apology against some articles produced by some monks in Spain," is quite sarcastic. 
from the Gospel of Matthew about "the tares among the wheat" as a divine instruction that it was only after the Second Coming that Christ would separate the true believers from the heretics. It was not a prerogative of any human inquisition to do that in the present. This parable has often been quoted in this sense. ${ }^{82}$ The Spanish Inquisition had attacked Erasmus for interpreting it thusly and the famous humanist had defended himself and his interpretation through this apology. The value of this defence was immediately acknowledged. Sebastian Franck quoted it extensively and so did Castellio in his De haereticis. ${ }^{83}$

In De praestigiis this quotation goes on for several pages and then after its conclusion, Wier adds:

Christ did not quench the smoking wick nor break the bruised reed. From the beginning the wolf has pursued the little sheep, but by patient endurance the little sheep has always prevailed. ${ }^{84}$

These two sentences have no bearing whatsoever on Erasmus's preceding words. They actually are references to Castellio's De haereticis, and more specifically to the contributions to this book by David Joris. ${ }^{85}$ People who were well acquainted with the contents of Castellio's attack on Calvin would have acknowledged this and understood what it stands for: Wier was identifying himself as a supporter of Castellio and as a spiritualist.

\section{Then, What about Demons?}

Advocating something by quoting Joris created a problem, however. David Joris did not believe in an anthropomorphic Devil. For him the Devil was the symbol of evil - an evil that could only thrive in people who had chosen to be sinful. Good and bad were both present in people's souls. People who chose to lead

82 Roland H. Bainton, "The Parable of the Tares as the Proof Text for Religious Liberty," Church History 1 (1932), 57-89.

83 Sebastian Franck, Chronica, Zeijt büch und geschijcht bibel von anbegyn biss inn diss gegenwertig M.D. xxxi. jar (Strasbourg: Balthasar Beck, 1531), fols. 454rv-455v; Castellio, De haereticis (see above, n. 38), 81-88.

84 De praestigiis (1568), 733. The translation is taken from Wier, Witches, Devils and Doctors (see above, n. 4), 535, with one exception. In the Latin text Wier speaks of an oviculam, which in my view should be translated as "[female] little sheep" and not as in the English translation as "lamb": if Wier had wished to refer to a female lamb, he would have used the term agna.

85 On this see De Waardt, "Witchcraft, Spiritualism and Medicine" (see above, n. 3), 385-387. 
a proper life suppressed the bad and chose the good, so they suppressed "the Devil" and chose to lead a godly life.

But in his De praestigiis, Wier argued that it was not the supposed witches but demons who did all the evil ascribed to, as he put it, "those demented old women who are deluded by the demon." ${ }^{86}$ Females were misled by evil spirits, he contended, who had no problem in making them believe that they were responsible for disasters they had perhaps wished to happen, but were really unable to bring about. To explain why they were willing to believe this was not so difficult, stated Wier, for women were feeble-minded and were easily deceived. This danger was even larger for a woman whose brain was degraded by an excessive amount of black bile, for this would make her melancholic. An excess of this humour would, certainly when putrefied, cause them to regard hallucinations that were actually brought about by demons as real. So Wier flatly denounced women as stupid and inclined to easily fall victim to demonic fraud.

But to what extent did he mean what he wrote? To start with the argument about "demented women": in his book Wier repeatedly underlined that women as a category are simple-minded, but when talking about individual women he was far less negative. Actually he was often quite positive. The best example is his qualification of his second wife Henrica Holt of whom he wrote that she was able to withstand the praestigia of demons. ${ }^{87}$ Women in general were supposed to be defenceless against these praestigia, but then, individual women were fully able to withstand all demonic tricks with the help of their sincere faith. This more or less implied that judges, all of them male, who sent supposed witches to the stake allowed themselves to be deluded by demonic schemes. Wier treated quite a few other individual women with a similar amount of respect.

And as to the role of the demons: he needed to provide his readers with a replacement for the usual suspects-the demented old women. To exonerate these he needed to inflate the powers of the demons. It cannot be emphasized enough that it was his aim to exculpate women. His book was meant to convince the judges and other magistrates who had to decide whether the evidence brought in against these suspects was well-founded. He fully realised that in order to convince them he had to adapt his argument to the capabilities of his audience. In 1567 , he published his own vernacular version of De praestigiis in reaction to a literal German translation of the Latin original by the Basel pastor

86 Wier, De praestigiis (see above, n. 4), 24.

87 "Novit illas optime coniunx mea altera, Henrica Holtia, mire diabolicis praestigijs ex viva fide inimica." Wier, De praestigiis (1577), 417. 
Johann Füglin. In the foreword, Wier showed great annoyance with the translator's approach because Füglin had misunderstood much of what Wier had written. But he also criticized the idea as such of a literal translation of his original text:

In the Latin version much has furthermore been written that not everybody can put into words or understand in the German language, [proof of which is that] he on many places holds on to the Latin terms. Many things that for scholars can be phrased in Latin, cannot be served to simple people. Who reads my German books and compares these to the other ones, will discover much that is not mentioned or described in the Latin version. ${ }^{88}$

His translation was indeed much simpler than the Latin original and was clearly meant for magistrates who were unable to understand Latin. In other words: the Latin original was intended for academically trained lawyers and magistrates, the German version for the aldermen who staffed the countryside benches. So Wier adapted his argument to the capacities of the audiences (plural) he intended to serve. That makes it all the more plausible that he adjusted his argument to what he thought his readers were capable of understanding. If these were convinced that demons were very powerful, then he gave them these evil spirits on a plate as substitutes for women. And when his readers believed that women were generally weak-minded then he used that bias as an argument to exculpate them. His brother Matthias had used a very similar argument when explaining how one should introduce people to the truth of spiritualism:

No man ought to utter forth his words in vain. All men cannot be called by the same terms, but it must be governed according to the quality of every one. To them who are rude as yet, nothing of the Sublime Mysteries may be talked of, but they first to be admonished, to put off their outside thicker barks: and if they accept that counsel, they may be admitted to discourses of Higher matters, and so by degrees may be yet farther proceeded with, until no Root of sin any more appeareth. But he who is not Faithful in lower matters, the more Sublime may not be proposed to him, or else the discourse would be holden to no purpose. ${ }^{89}$

88 Wier, De praestigiis daemonum. Von Zauberey, wo her sie iren Ursprung hab ... (s.l., 1567), Vorred, fol. $\mathrm{b}^{*}$ iij.

89 Wier, The Narrow Path (see above, n. 52), $5^{2}$. 
One final argument will help to show that in his view demons were perhaps believed to be powerful but were in fact unable to do anything. In 1577, Wier added as a sort of appendix to the Latin edition of that year of his De praestigiis, a text called Pseudomonarchia Daemonum (The Pseudo-Monarchy of Demons). In his very short introduction to this text he explained that he had used what was really a grimoire and that he had decided to include it in his book in order to show the fraudulent character of cunning folk. The title he gave it was not the original one. That referred to King Solomon as the first author. The text, which numbers just a few pages, surveys the hierarchy of the demons. Does this imply that Wier suddenly believed they did have powers? I think it does the opposite. The title that Wier gave it says that it is about the "PseudoMonarchy of Demons," in other words about the "Fake Rule of Demons," implying that it dealt with a power that did not exist. It is about deception and the title should be interpreted as just another coded message.

Johan Wier's dealings with the foundations and implications of the witchcraft issue show that spiritualism could be more, much more than just an individualistic religious conviction. His attempt to stop the prosecution of supposed witches by replacing the usual suspects with demons as new scapegoats was clearly practical, also in the sense that he used rhetorical tricks. He himself did not believe in demonic power, but by conjuring up the demons as the real enemies, he hoped to divert the attention of the demonologists away from female suspects. As a professional physician he clearly was a conservative man, but in matters of tolerance and judicial procedures he was without doubt much more unconventional. 